\title{
Effect of nodule count and austempering heat treatment on segregation behavior of alloying elements in ductile cast iron
}

\author{
*E. Akbarzadeh Chiniforush ${ }^{1}$, N. Iranipour ${ }^{1,2}$ and S. Yazdani ${ }^{1}$ \\ 1. Faculty of Materials Engineering, Sahand University of Technology, Tabriz, Iran; \\ 2. Deakin University, Institute for Technology Research and Innovation, Geelong, Australia
}

\begin{abstract}
The equilibrium partition ratio, $\mathrm{k}$, has been measured for $\mathrm{Mn}, \mathrm{Mo}, \mathrm{Si}, \mathrm{Ni}$ and $\mathrm{Cu}$ in a ductile iron with composition (wt. \%): $3.45 \mathrm{C}, 0.25 \mathrm{Mn}, 0.25 \mathrm{Mo}, 2.45 \mathrm{Si}, 0.5 \mathrm{Ni}$ and $0.5 \mathrm{Cu}$ with different nodule counts obtained from different section sizes of $13,25,75 \mathrm{~mm}$ in the as cast, austenitized (at $870{ }^{\circ} \mathrm{C}$ for times 1,4 and 6 hours) and austempered (at $375{ }^{\circ} \mathrm{C}$ for times 1 to $1,440 \mathrm{~min}$ ) samples. Results show that $\mathrm{Mn}$ and Mo segregate positively at cell boundaries, but $\mathrm{Si}, \mathrm{Ni}$ and $\mathrm{Cu}$ concentrate in an inverse manner in the vicinity of graphite nodules and there is a depletion of these elements at cell boundaries. Segregation curves for $\mathrm{Ni}$ and $\mathrm{Cu}$ are more smooth than for $\mathrm{Si}$. Carbide formation has been observed at cell boundaries. Based on the results, the partition ratios for all elements decrease with increasing the nodule count. More carbide with coarser morphology has been observed in the microstructure with a lower nodule count. Austenitization for a longer time can decrease partition ratio, but cannot eliminate it entirely. Increasing the austenitization temperature has the same effect.

Austenitizing parameters have no significant effect on carbides volume fraction. The kinetics of austempering is faster in higher nodule counts and subsequently better mechanical properties including higher ductility, strength and toughness have been observed for all austempering conditions studied.
\end{abstract}

Key words: segregation; ductile iron; austenitization; austempering
CLC numbers: TG143.5
Document code: A
Article ID: 1672-6421(2016)03-217-06

\begin{abstract}
A lloying elements are frequently added into ductile iron for several purposes such as improvement of mechanical properties and/or austemperability. Segregation of alloying elements during eutectic solidification of the iron results in complexities in putting them into operation and deteriorates the mechanical properties ${ }^{[1]}$. With segregation of alloying elements at certain areas, the non-uniformity of elements cause the existence of several phase diagrams across the microstructure in which results in a variable phase transformation kinetics and consequently affects the heat
\end{abstract}

\section{* E. Akbarzadeh Chiniforush}

Female, born in 1987, final year post graduate student in the field of Materials Science and Engineering in Sahand University of Technology, Tabriz, Iran. She is doing her MSc. thesis under the supervision of Professor Sasan Yazdani. She is working in the fields of advanced nanostructured steels and segregation of elements in steels and cast irons in Professor Yazdani's research group which has over 70 publications of research papers in journals such as Scripta Materialia, Materials Design, Materials Science and Engineerin A, China Foundry, etc.

E-mail: E_akbarzadeh@sut.ac.ir (E. Akbarzadeh Chiniforush), Yazdani@sut.ac.ir (S. Yazdani )

Received: 2016-04-21; Accepted: 2016-05-20 treatment process and hardenability of iron. Formation of martensite at intercellular boundaries in austempered ductile iron because of delaying the austempering transformation kinetics is majorly as a result of segregation of $\mathrm{Mn}$ and carbide forming elements in these regions ${ }^{[2,3]}$.

Segregation also results in waste in the content of alloying elements in the eutectic cells and subsequently weakens the mechanical properties of the iron in this manner ${ }^{[4-7]}$.

The aim of this present study is to determine the equilibrium partition ratios for $\mathrm{Mn}, \mathrm{Mo}, \mathrm{Si}, \mathrm{Ni}$ and $\mathrm{Cu}$ in an alloyed ductile iron and to determine the effect of section size of the samples and their nodule counts on this ratio. The effect of austenitization parameters has also been investigated. Finally, the nodule counts' effects on mechanical properties have been determined.

\section{Experimental procedure}

Ductile iron was melted in a rotary furnace and then cast into Keel blocks. The sizes of the Keel block are 
presented in Table 1. FeSiMg alloy was used for spheroidisation and FeSi alloy for nucleation. Samples for microstructural analysis, impact and tensile tests were machined off from the bottom sections of the Keel blocks. A set of samples for microstructural analysis, were austenitizied at $870{ }^{\circ} \mathrm{C}$ for 1, 4 and 6 hours, respectively, and then air cooled to room temperature. Impact and tensile specimens of medium and large thickness were austenitized for 1 hour at $870{ }^{\circ} \mathrm{C}$ in an electric

Table 1: Dimensions of casting Keel blocks (mm)

\begin{tabular}{|cccc|}
$\begin{array}{c}\text { Dimensions of } \\
\text { blocks }\end{array}$ & I & II & III \\
\hline A & 13 & 25 & 75 \\
B & 40 & 54 & 125 \\
C & 50 & 75 & 100 \\
D & 100 & 150 & 185 \\
E & 175 & 175 & 175 \\
\hline
\end{tabular}

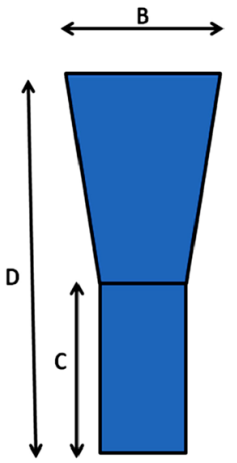

A

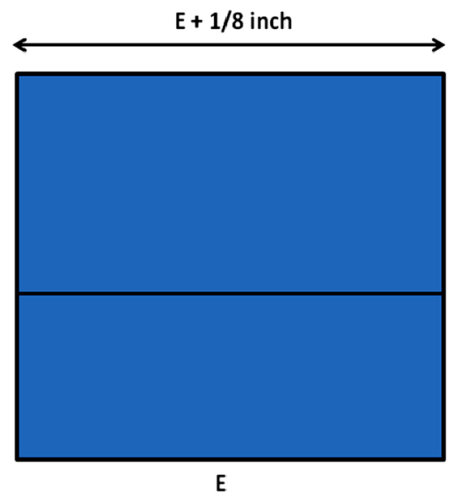

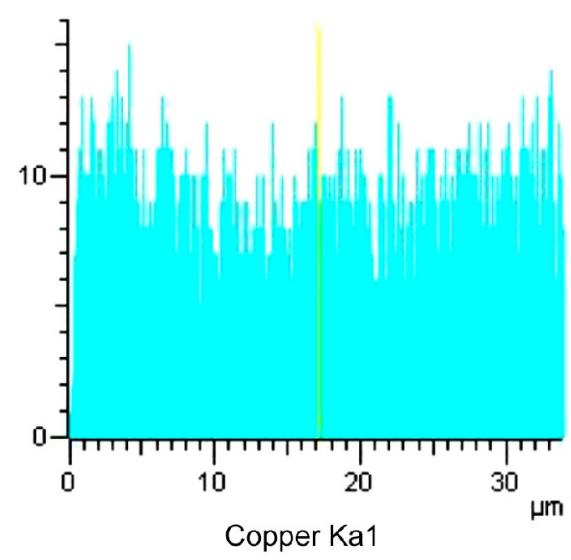

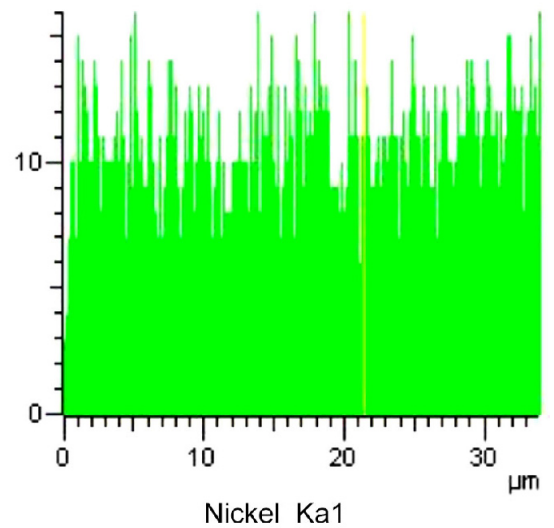

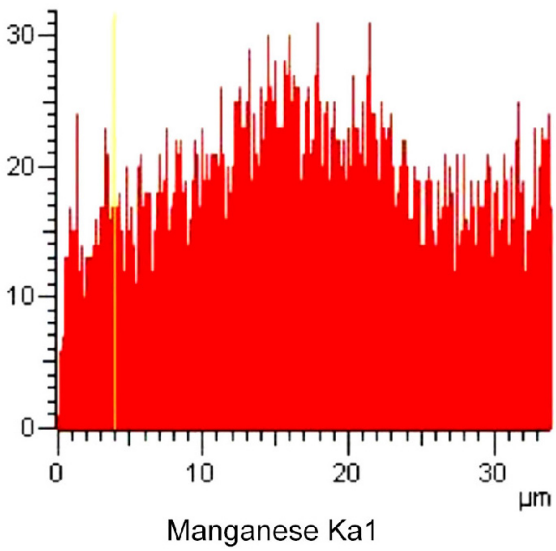

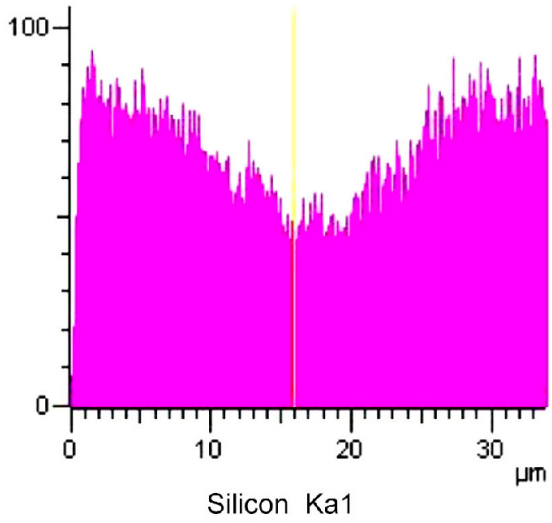

salt bath furnace and subsequently austempered for times in the range of 1 to $1,440 \mathrm{~min}$ at $375^{\circ} \mathrm{C}$ in a salt bath and then cooled to room temperature. Microstructural features were studied using Olympus PMG3 ${ }^{\mathrm{TM}}$ optical and Cam Scan MV$2300^{\mathrm{TM}}$ scanning electron microscope (SEM) operating at 30 $\mathrm{kV}$ to determine the distribution of alloying elements in the microstructure. The technique adopted was to scan a line from the edge of a graphite nodule through the matrix and across a cell boundary in order to determine the concentration of elements throughout the matrix and in cell boundary areas (Fig. $1)$. The results were recorded in the forms of graphs showing the variation of the elements' concentration in distance from the graphite nodule (Fig. 2). Partition ratios of alloying elements

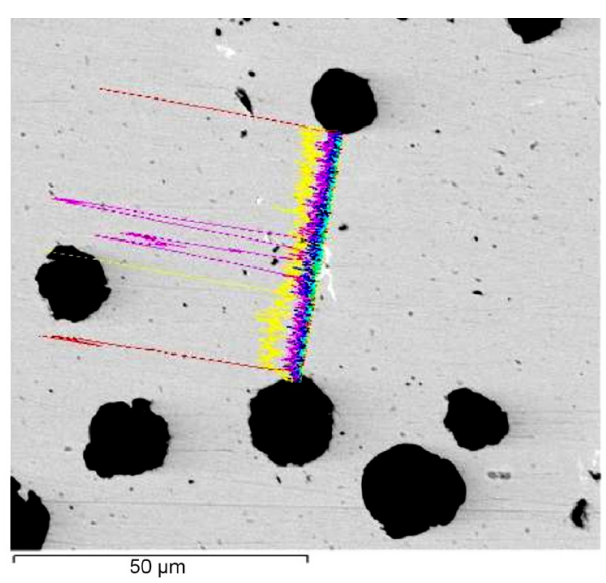

Fig. 1: Schematic of line scan micro-analyses between two graphite nodules

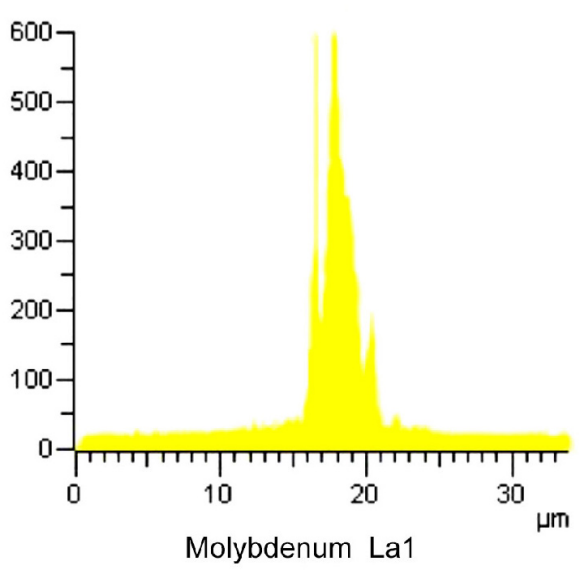

Fig 2: Typical distribution of $\mathrm{Cu}, \mathrm{Mn}, \mathrm{Mo}, \mathrm{Ni}$ and $\mathrm{Si}$ between two graphite nodules in the matrix 
were calculated in both as cast and austenitized specimens with measuring the ratio of element concentration in first to freeze regions, regions around the graphite nodule, to the element concentration in last to freeze regions, eutectic cell boundaries. Impact and tensile tests were carried out on austempered samples.

\section{Results and discussion}

\subsection{Microstructure}

Nodule counts of 110, 185 and $260 \mathrm{~mm}^{-2}$ were obtained from the different thicknesses $(13,25,75 \mathrm{~mm})$ of Keel blocks as a result

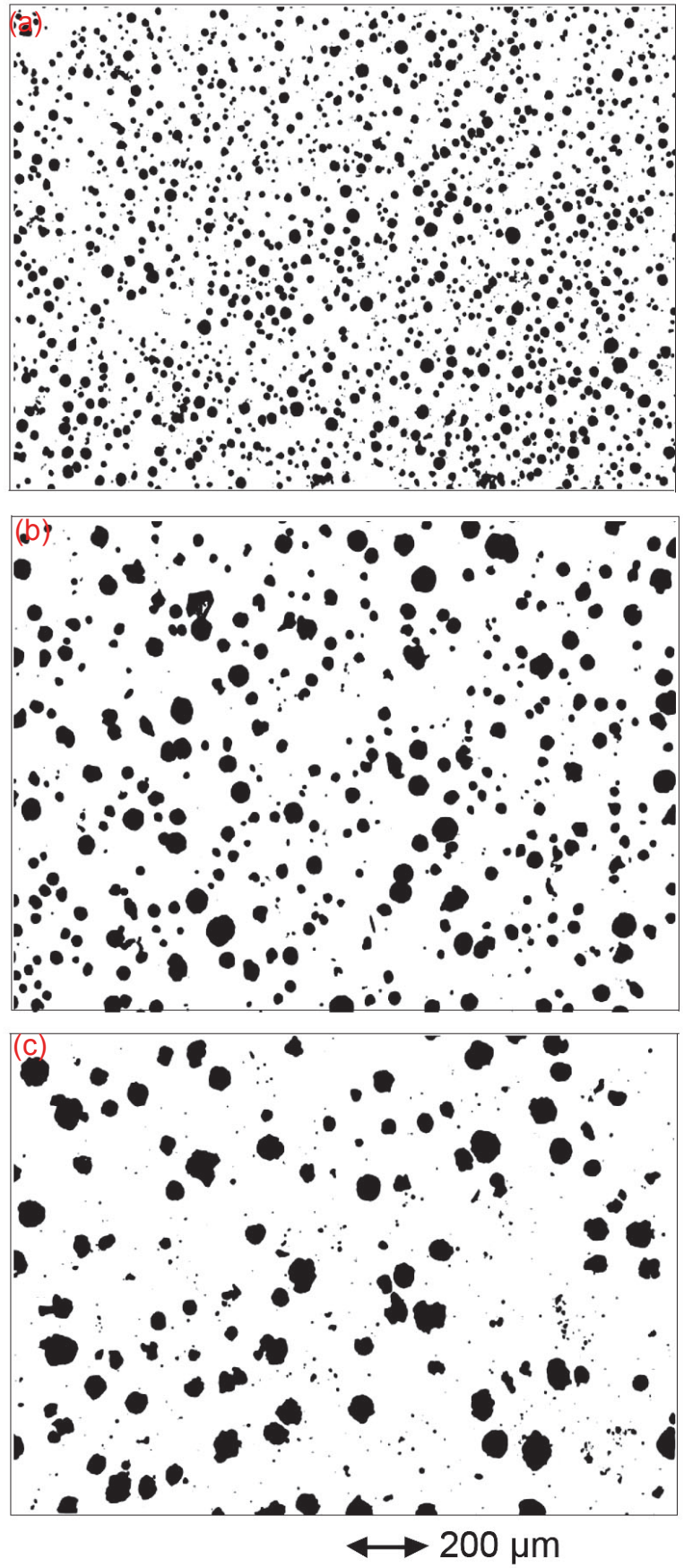

Fig 3: As polished samples with different nodule counts obtained from different section sizes of $13,25,75 \mathrm{~mm}$ : (a) $265 \mathrm{~mm}^{-2}$, (b) $185 \mathrm{~mm}^{-2}$, (c) $110 \mathrm{~mm}^{-2}$ of various cooling rates in each section size. By increasing the thickness of blocks, the cooling rate decreases and consequently the nodule count of iron decreases (Fig. 3 and Table 2). The microstructure across the graphite nodules consists of a mixture of pearlite and ferrite. The pearlite volume and lamella spacing increases with respect to nodule count reduction. The narrow bright phase between the middle part of the pattern are carbides which were formed in eutectic cell boundaries (Fig. 4).

Table 2: Microstructure characteristics of blocks

$\begin{array}{ccccc}\begin{array}{c}\text { Block } \\ \text { Number }\end{array} & \begin{array}{c}\text { Section } \\ \text { size } \\ \mathrm{mm}\end{array} & \begin{array}{c}\text { Nodule } \\ \text { count } \\ \mathrm{mm}^{-2}\end{array} & \begin{array}{c}\text { Nodule } \\ \text { average } \\ \text { diameter } \\ \mu \mathrm{m}\end{array} & \begin{array}{c}\text { Ferrite } \\ \text { vol\% }\end{array} \\ \text { I } & 13 & 265 & 18 & 20 \\ \text { II } & 25 & 185 & 25 & 10 \\ \text { III } & 75 & 110 & 35 & 5\end{array}$

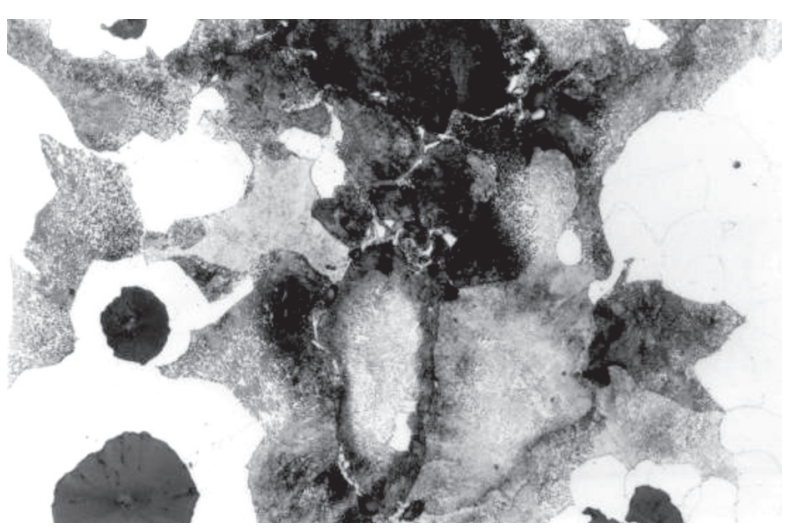

Fig 4: Microstructure of as cast ductile iron indicating carbides in eutectic cell boundaries

\subsection{Austempering reaction}

The austempering reaction in ductile irons is now relatively well understood. It is a two stage reaction that differs from single stage reaction in steels. The first event in stage $I$ is the formation of acicular ferrite from the austenite close to the graphite nodules in the eutectic cells and then progressively towards the intercellular boundaries. The ferrite formation is accompanied by carbon diffusion which enriches the surrounding austenite. The austenite carbon content reaches $1.8 \%-2.2 \%$. This austenite is thermally and mechanically stable. Unreacted austenite is thermally unstable and transforms to martensite during cooling to room temperature. The desired austempered structure is consisting of stable austenite and acicular ferrite, a structure known as ausferrite. If the austempering time is extended further, stage II reaction occurs. The reacted stable austenite decomposes into ferrite and carbide. This transformation is detrimental to mechanical properties and should be avoided ${ }^{[10-13]}$. Figure 5 show typical micostructural changes during austempering in the present study. Figure 5(a) shows how acicular ferrite has started to form 

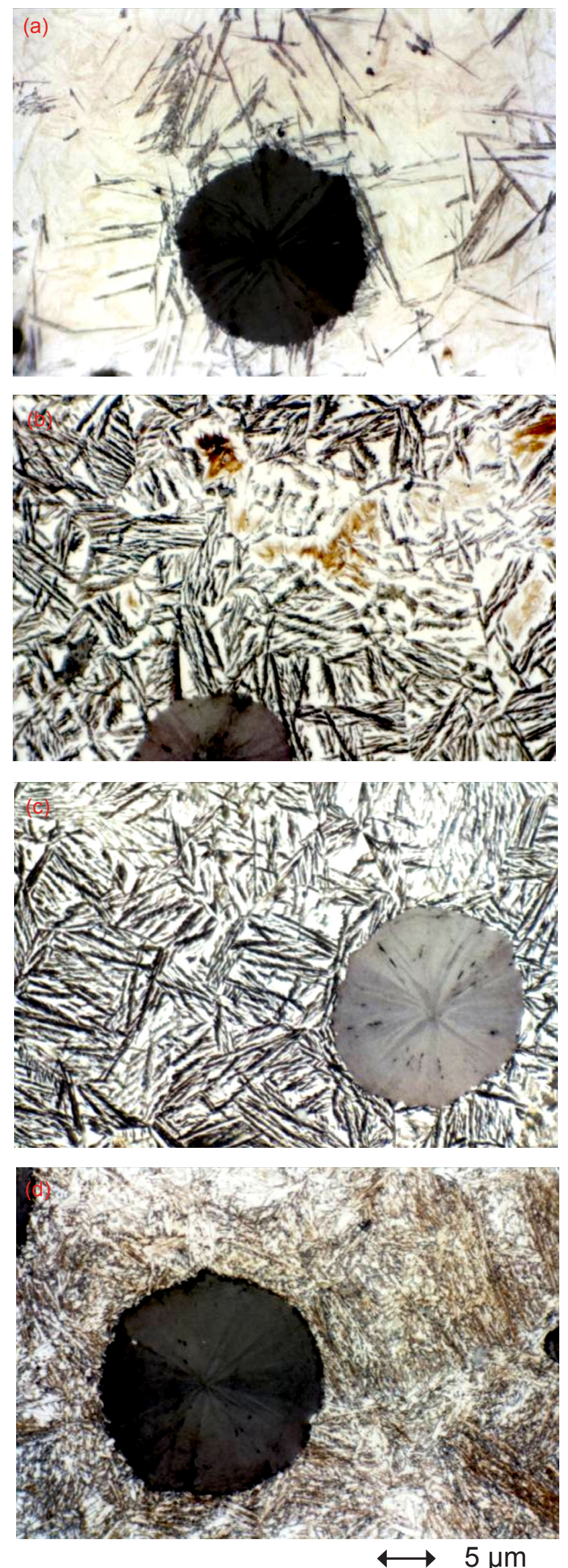

Fig 5: Microstructure of samples austempered at $375^{\circ} \mathrm{C}$ with different holding times: (a) 1, (b) 10, (c) 60 and (d) 1,440 $\min$ in areas surrounding the graphite nodules after austempering for $1 \mathrm{~min}$ at $375{ }^{\circ} \mathrm{C}$. The remaining areas of the matrix show martensite which forms from the low carbon austenite. Figure 5(b) shows that the stage I reaction is well underway after 10 min. Figure 5(c) shows that the ausferrite formation is almost completed within the microstructure. The platelet structure of ausferrite is evident in the microstructure. Figure 5(d) shows that the platelet structure is no longer clearly defined after 1,440 $\min$ as the result of the onset of stage II reaction.

\subsection{Micro-analyses}

The graphs obtained from line scanning of a pattern between graphite nodules in sample Y1 (shown in Fig. 1), illustrate distribution of $\mathrm{Si}, \mathrm{Ni}, \mathrm{Cu}, \mathrm{Mn}$ and Mo across two adjacent nodules (Fig. 2). The partition ratios of each element in each block are calculated and represented in Table 3. Each result is the average of 8 measurements to reduce the possible errors. According to the element distribution in graphs, Mn and Mo segregate positively at eutectic cell boundaries and the least concentration is observed in vicinity of graphite nodules. The partition ratios for Mn and Mo are less than unity (Table 3). These elements are rejected continuously from the solidification plane boundary to the liquid during eutectic solidification. Carbide forming elements segregate positively and they are located in the left side of $\mathrm{Fe}$ in the periodic table of the elements. These elements decrease the thermodynamic activation energy of carbon ${ }^{[8]}$. Ni, $\mathrm{Cu}$ and $\mathrm{Si}$ segregate negatively around the graphite nodules. The partition ratios of these elements are over unity (Table 3$)^{[9]}$. Such graphite forming elements which have a tendency to remain in the first to solidified volume of liquid, are located in the right side of $\mathrm{Fe}$ in the periodic table. These elements increase the thermodynamic activation energy of carbon. According to the appearance of concentration peak for Mo in resultant SEM EDS graphs in the area which is related to the bright phase appeared within intercellular boundaries, and the knowledge of the intense carbide forming tendency of the Mo, it is presumed that the bright intercellular phases are carbide compounds of Mo (Fig. 4) ${ }^{[10-13]}$.

Comparison of element distribution graphs in various samples with different nodule counts and their segregation coefficients indicates that the partition ratio increases with increasing the section size and consequent reduction in nodule count. In addition, the fraction of Mo carbides increases. Several nodule counts are obtained as a result of different cooling rates at different parts of Keel blocks. By decreasing the nodule count at thicker sections, the cooling rate decreases and diffusion of elements in the solid could be taken into accoun. As a result, the accommodation of elements happens in the vicinity of graphite nodules for negatively segregated elements and in intercellular regions for positively segregated elements. This behavior reduces the partition ratio in the microstructure. The line scan micro-analyses and calculated partition ratios in the austenitized samples indicate that austenitization for 1 hour at $870{ }^{\circ} \mathrm{C}$ has not any significant effect on element distribution and resultant partition ratio (Table 4). This is the result of relatively high 
Table 3: Partition ratios of elements in samples with different nodule counts

\begin{tabular}{cccccccc} 
& Nodule count & \multicolumn{5}{c}{$k$} \\
\cline { 3 - 7 } Sample & $\mathrm{mm}^{-2}$ & $\mathrm{Mn}$ & $\mathrm{Si}$ & $\mathrm{Ni}$ & $\mathrm{Cu}$ & Mo \\
$\mathrm{A}$ & 110 & 0.41 & 2.36 & 2.08 & 2.03 & 0.1 & 0.12 \\
$\mathrm{~B}$ & 185 & 0.5 & 1.85 & 1.5 & 1.66 & 0.12 \\
$\mathrm{C}$ & 265 & 0.64 & 1.66 & 1.33 & 1.25 & 0.12
\end{tabular}

Table 4: Partition ratiosof elements in austenitized samples

\begin{tabular}{cccccccccc} 
Sample & $\begin{array}{c}\text { Austenitizing } \\
\text { Temperature } \\
\left({ }^{\circ} \mathrm{C}\right)\end{array}$ & $\begin{array}{c}\text { Austenitizing time } \\
(\mathrm{h})\end{array}$ & - & $\mathrm{Mn}$ & $\mathrm{Si}$ & $\mathrm{Ni}$ & $\mathrm{Cu}$ & $\mathrm{Mo}$ \\
\cline { 4 - 8 } & & - & 0.5 & 1.85 & 1.5 & 1.66 & 0.125 \\
1 & 870 & 1 & 0.54 & 1.83 & 1.33 & 1.66 & 0.1 \\
2 & 870 & 4 & 0.64 & 1.7 & 1.29 & 1.44 & 0.1 \\
3 & 870 & 6 & 0.75 & 1.33 & 1.25 & 1.37 & 0.1
\end{tabular}

diffusion coefficients for substitutional elements in iron such as $\mathrm{Mn}$ and $\mathrm{Ni}$. Longer austenitizing time is not recommended because of possible grain growth and adverse effect on mechanical properties ${ }^{[14]}$.

\subsection{Mechanical properties}

The Charpy impact energy, elongation, ultimate tensile strength and yield strength variations of samples with 110 and 185 graphite nodules $\mathrm{mm}^{-2}$ as a function of austempering time are illustrated in Fig. 6. In both samples, increasing the austempering time results in improvements of properties and
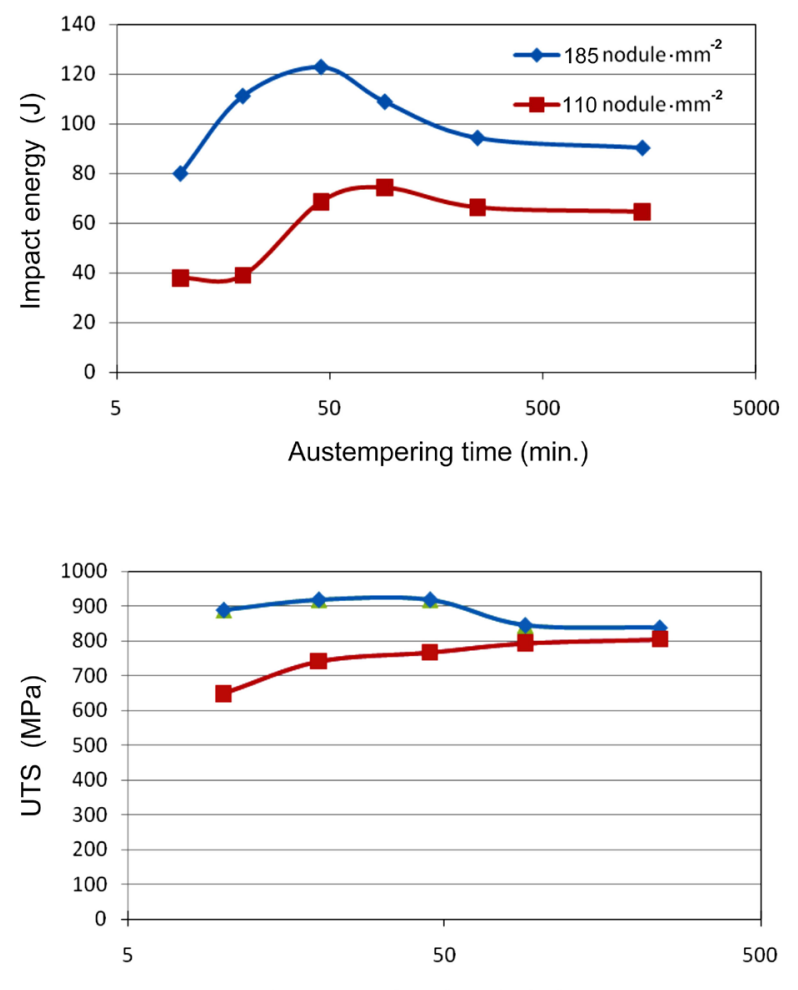

Austempering time (min.) after reaching maximum value, deteriorations in properties begin to take place. This is as a result of variations in type and amount of microstructural constituents which take place during stage I and II austempering reaction. Quenching the samples from austenitization temperature to austempering temperature and holding in this temperature results in starting the first stage reaction of austempering reaction. As the transformation progresses, in the final microstructures, the amount of martensite decreases while the ausferrite content increases. Consequently, mechanical properties improve until the microstructure becomes fully ausferritic and this is the duration in which optimum
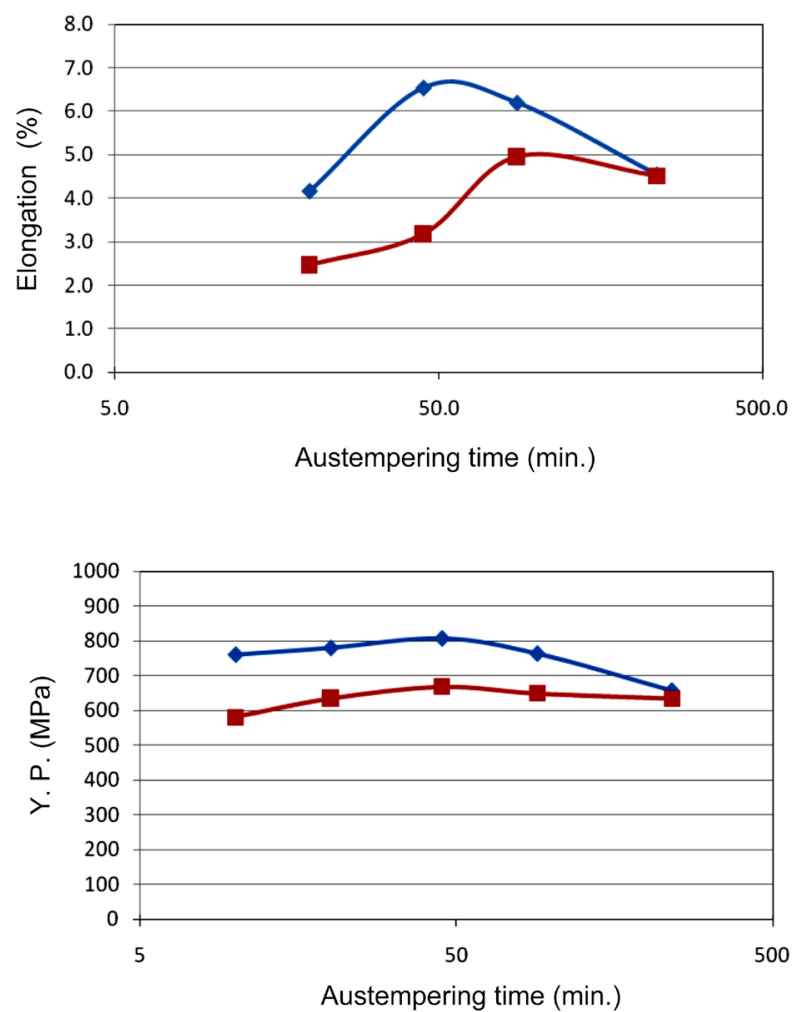

Fig 6: Variation of Charpy impact energy, elongation, ultimate tensile strength and yield strength as a function of austempering time (min) 
values of mechanical properties could be obtained. Subsequent fall in the properties is the result of beginning of the stage II austempering reaction which includes formation of carbides from carbon enriched austenite that weakens the properties of the iron. The changes in properties in higher nodule count samples are faster. Attaining optimum properties in samples with 185 graphite nodules $\mathrm{mm}^{-2}$ take place in about 45 minutes while it takes about 90 minutes for samples with 110 nodules $\mathrm{mm}^{-2}$. A higher degree of segregation, a lack of suitable ferrite nucleation sites (around graphite nodules), and long ferrite growth distances to encounter each other in a lower nodule count sample, make the transformation rate slower in comparison with a higher nodule count sample.

The segregation of alloying elements in the intercellular regions causes the delay of austempering reaction in these regions. This is the main disadvantage of alloyed ductile iron during austempering of thicker sections ${ }^{[14,15]}$.

Samples with 110 nodules $\mathrm{mm}^{-2}$ have lower impact energies, elongation and strength values. This is because of more severe segregation and consequently increasing the amount, size and formation of intercellular carbides and accompanying micro cavities and increasing the formation of intercellular martensite. This results in ewer crack formations, lower propagation energies and diminished properties.

\section{Conclusions}

By studying the segregation behavior of alloying elements in ductile iron containing $3.45 \mathrm{C}, 0.25 \mathrm{Mn}, 0.25 \mathrm{Mo}, 2.45 \mathrm{Si}, 0.5 \mathrm{Ni}$ and $0.5 \mathrm{Cu}$ in wt. $\%$, the following conclusions can be drawn:

(1) By increasing the cast iron section size, the solidification rate decreases and consequently the amount of graphite nodules decreases. This affects the ferrite/pearlite ratio and increases pearlite lamella spacing.

(2) $\mathrm{Ni}, \mathrm{Cu}$ and $\mathrm{Si}$ have negative and inverse segregation patterns and concentrate in the vicinity of graphite nodules while $\mathrm{Mn}$ and Mo segregate positively in intercellular regions. Segregation coefficients of $\mathrm{Ni}, \mathrm{Cu}$ and $\mathrm{Si}$ are more than unity and for Mn and Mo it is less than unity. Segregation of Mo accompanied the formation of eutectic carbides within intercellular regions. By decreasing the nodule count, the partition ratio increases for all alloying elements studied and more carbide is observed in the microstructure.

(3) Austenitizing treatment for custom temperatures and durations does not have a significant effect on the partition ratio. By increasing the nodule count, the mechanical properties of ADI improves.

(4) Austempering reaction is faster in high nodule count samples and optimum mechanical properties are attained in a shorter austempering time.

\section{Acknowledgments}

Authors are grateful to the Sahand University of Technology for providing the research facilities and financial support.

\section{References}

[1] Jolley G. Segregation During Solidification of Nodular Cast Iron, The Solidification of Metals, London, Iron and Steel Inst., 1968, 110: 242-250.

[2] Faubert G P, Moore D J, Rundman K B, et al. Heavy section $A D I$ : microsegregation, microstructure, and tensile properties. AFS Trans, 1989, 97: 747-756.

[3] Schissler J M, and Saverna J. The effect of segregation on the formation of austempered ductile iron. Journal of Heat Treating, 1985, 4(2): 167-176.

[4] Chang S, and Stefanescu D M. Microsegregation in Spheroidal Graphite Iron: A Numerical Model and its Validation. Advanced Materials Research, 1997, 4-5: 491-498.

[5] Lin B Y, Chen E T, and Lei T S. The effect of segregation on the austemper transformation and toughness of ductile irons. Journal of Materials Engineering and Performance, 1998, 7(3): 407-419.

[6] Lekakh S, Richards V, and Medvedeva N. Effect of Si segregation on low temperature toughness of ductile iron. AFS Trans, 2012, 120: 319-326.

[7] Alabi G F A, and Aluko F. Production of Austempered Ductile Iron with Optimum Sulphur level for effective Mechanical Properties. The International Journal of Engineering and Science (IJES), 2013, 2(12): 67-71.

[8] Boeri R, and Weinberg F. Microsegregation in ductile iron. In: Proceedings of the 93rd AFS Casting Congress, 1989.

[9] Lin B Y, Chen E T, and Lei T S. The effect of segregation on the austemper transformation and toughness of ductile irons. Journal of Materials Engineering and Performance, 1998, 7(3): 407-419.

[10] Yazdani S, and Elliott R. Influence of molybdenum on austempering behaviour of ductile iron, Part 1 Austempering kinetics and mechanical properties of ductile iron containing $0.13 \%$ Mo. Materials Science and Technology, 1999, 15(5): 531-540.

[11] Yazdani S, and Elliott R. Influence of molybdenum on austempering behaviour of ductile iron, Part 2 - Influence of austenitising temperature on austempering kinetics, mechanical properties, and hardenability of ductile iron containing $0.13 \%$ Mo. Materials Science and Technology, 1999, 15(5): 541-546.

[12] Yazdani S, and Elliott R. Influence of molybdenum on austempering behaviour of ductile iron, Part 3 Austempering kinetics, mechanical properties, and hardenability of ductile iron containing $0.25 \%$ Mo. Materials Science and Technology, 1999, 15(8): 885-895.

[13] Yazdani S, and R Elliott. Influence of molybdenum on austempering behaviour of ductile iron, Part $4-$ Austempering behaviour of ductile iron containing $0.45 \%$ Mo. Materials Science and Technology, 1999, 15(8): 896-902.

[14] Borowiecki B and Mak S. Segregation of Admixing Elements in the Boundary Layer of the Main Inlet of a Ductile Iron Casting. Archives of Foundry Engineering, 2013, 13 (2):10-17.

[15] Yazdani S and Ardestani M. Effect of sub-zero cooling on microstructure and mechanical properties of a low alloyed austempered ductile iron. China Foundry, 2007, 4(2): 120123. 